\title{
Bus Rapid Transit: what can change in travel strategies?
}

\author{
M. S. G. Tobias ${ }^{1,2}$ \& B. M. R. Oliveira ${ }^{1,2}$ \\ ${ }^{1}$ University of Amazônia, Brazil \\ ${ }^{2}$ Urban Mobility, Brazil
}

\begin{abstract}
The implementation of a Bus Rapid Transit system (BRT) is a reality in many Brazilian cities. In Belém, where the public transportation system is mainly operated by buses with no integration, BRT is expected to serve: bus users on a larger scale; users of other modes of transportation, such as alternative collective transport system and microbuses; and users of individual modes of transportation, such as cars, taxis and motorcycle taxis. Therefore, it is expected that users change their travel strategies, especially those who are located in the area surrounding the project. This study intends to explore the effects of BRT on townspeople and on public and private transport users regarding their travel strategies. The study is composed of an initial discussion about BRT projects in Brazilian cities and the development of a case concerning the routes, which are part of BRT system in Belém, Pará, Brazil. The investigation involved focus groups in a one-mile radius around the route. A questionnaire was applied using the stated preference technique, with questions about socioeconomic profile, travel standards, inputs related to the current transport system and strategies for current and future travels after the implementation of BRT system. Among the results achieved, BRT was found to cause tremendous impacts on travel strategies of townspeople and public transport users in the surveyed area. Cyclists expect the system to be integrated with the implementation of bicycle racks. In general, the survey has shown that users tend to change their travel strategies and that BRT is positively regarded by public transport users, as something that would improve their urban mobility.
\end{abstract}

Keywords: BRT, integration, public transport, travel strategies. 


\section{Introduction}

The urban centers are developing more and more and that creates greater needs for movement. The spaces in cities have become scarce regarding urban mobility, which demands from the local traffic and transportation authorities the development of integrated transportation systems in order to improve the various types of displacement.

Within the current public transportation integration systems implemented around the world, there is the Bus Rapid Transit (BRT), which presents several advantages in solving the problems of mobility. This transportation consists in a high capacity bus system, which enables a fast, comfortable, efficient and quality service. Using exclusive corridors, the BRT has attractive features from modern urban transportation systems, with a cheaper usage cost. The BRT has its origin based on the traditional bus systems. However, it has little in common with its predecessors.

In most of BRT systems, which were successfully implemented, there are: exclusive or preference corridors for traffic of public transport; fast boarding and disembarking through platforms on the same level of vehicles (platform-level boarding); off-board fare collection system; modern and high capacity vehicles with cleaner technologies; cost free transference between routes, modal integration at stations and terminals; rigorous programming and control of operation; traffic signals and information to passengers.

The implementation of BRT systems is a reality in several Brazilian cities and in Latin America. In Brazil, BRT has already been successfully implemented in Curitiba city. Nowadays this city is considered as model to be followed in terms of urban transportation, because it presents all the features of a high quality service. It is considered a "complete BRT" system. In Latin America there are various examples of BRT system implementation. It is possible to highlight the case in Bogotá, Colombia, where there is another example of a "complete BRT" [1].

The perspective of changing the operational logic of the system implies alterations on the way and on the usage of the space where the public transportation is found. In this case, the BRT system is more than an alteration in how the public transportation service is offered, but also a new perspective of mobility with sustainability in big cities, which requires the passengers to review their travel strategies.

Thus, changes in users' travel strategies must be considered, especially in the area that surrounds the project, in order to gather investments for soil usage and complementary transportation planning. This study intends to explore the effects of BRT on townspeople and on public and private transport users of the area that surrounds the studied route. The study is composed by an initial discussion about BRT projects in Brazilian cities and the development of a case about a route which is part of BRT system in Belém, Pará, Brazil. Travel strategy is the decision making process regarding type of travel, destination, timetable, and mode of transportation to be used. 


\section{Travel strategies}

Travel strategies are conditioned according to people's activities. Displacements always depend on internal and external factors, and the process of choosing a mode of transport can be different among them [2]. When users plan a strategy for displacements, they tend to optimize them. In this case, users take into consideration their individual needs, family income, available resources, distance to be travelled, time spent on trip and available modes of transport.

More specifically, the choices could be made through the following features of the alternatives offered to the users [3]:

i) Modal alternatives;

ii) Service level;

iii) Price;

iv) Availability.

On the other hand, the users' behavior is conditioned by personal characteristics, previous experiences and the need for transportation usage.

The basic premises of this study are related to the expected changes with the implementation of an integrated transportation system in order to facilitate the displacements; therefore the change in travel strategies of urban transportation users in a certain space is based on the following hypotheses:

- $\quad$ The travel demand is derived from the activity demand [4].

- The spatial, temporal and interpersonal restrictions affect activities accomplishments [5].

- The characteristics of their lives affect the individual's activities and their decision for travel; the family and other social structures have influence on the travels and the individuals' behavior [6].

- The decisions about the travels and activities are dynamic [7] and the user's choice for a certain transportation service is based on the features of the offered service, as well as on substitute options. That creates a process of alternative selection [8].

In this study, the analysis of the behavior of the public transportation users in Belém is based on home interviews and focus groups, which are the target audience of the BRT system. The opinion research about the transportation system has theoretical ground on the concepts, methods, and marketing data gathering techniques on market research, with focus on the users' needs and attitudes [9].

\section{$3 \quad$ BRT in Brazil}

The BRT system is successfully present in 140 cities in the world, of which 18 are Latin American. Implemented in a pioneering way in Curitiba, Brazil, the BRT is a flexible concept, which can be set or tailored especially for the market and the physical environment where it operates. The BRT systems have also showed a potential for drastically reducing the $\mathrm{CO}_{2}$ emissions, because an optimization of existent routes is conducted for its correct implementation.

There's an expectation of increasing the BRT system in Brazil, because of the investments in the twelve host cities of the 2014 FIFA World Cup and more eight 
cities in the country. However, these projects are at different stages of development. In some cases, an advanced stage has been achieved in terms of conception, implementation and future perspectives of the systems. Some cities have conceived it as a part of a long term strategies for urban development, which will be used not only for meeting the existent demands, but also coordinate the urban growth in areas of interest.

Table 1: BRT in Brazilian cities.

\begin{tabular}{|c|c|}
\hline Brazilian cities & Project's aspects \\
\hline Recife & $\begin{array}{l}\text { Ongoing project for } 100 \text { kilometers of segregated } \\
\text { lanes with two serving axes. }\end{array}$ \\
\hline Rio de Janeiro & $\begin{array}{l}\text { Operating } 56 \text { kilometers and } 220,000 \text { passengers per } \\
\text { day. The system is being currently extended in order } \\
\text { to serve more than } 1.5 \text { million passengers. }\end{array}$ \\
\hline Porto Alegre & $\begin{array}{l}\text { Renovation in corridors with } 16.7 \text { kilometers, made } \\
\text { with concrete pavement and new stations, in order to } \\
\text { become a BRT system. }\end{array}$ \\
\hline Belo Horizonte & $\begin{array}{l}\text { The construction work will be concluded in } 2014 \text { with } \\
26 \text { kilometers for exclusive lanes, } 41 \text { special points } \\
\text { and five integration stations. }\end{array}$ \\
\hline São Paulo & $\begin{array}{l}\text { Since } 2007 \text {, it has already a system that is considered } \\
\text { as a BRT, which is called Expresso Tiradentes. It has } \\
\text { a } 33 \text { kilometers extension. } 40,000 \text { passengers use it per } \\
\text { day with four stations and two integration terminals. }\end{array}$ \\
\hline Salvador & $\begin{array}{l}\text { Project with } 8.6 \text { kilometers which comprise exclusive } \\
\text { lanes for articulated buses, three viaducts, five } \\
\text { flyovers and nine boarding and disembarking stations. } \\
\text { When it is concluded, the BRT will be integrated to } \\
\text { two other existent traffic corridors, which will total up } \\
49.3 \text { kilometers of traffic corridors with exclusive } \\
\text { lanes. }\end{array}$ \\
\hline Brasília & $\begin{array}{l}\text { Ongoing project for } 43 \text { kilometers of exclusive lanes, } \\
\text { articulated and bi-articulated buses, with integration to } \\
\text { underground and } 15 \text { stations. }\end{array}$ \\
\hline Belém & $\begin{array}{l}\text { Ongoing project with } 55 \text { kilometers comprised of } \\
\text { exclusive lanes and, at some points, separated for } \\
\text { articulated buses and } 40 \text { stations. }\end{array}$ \\
\hline
\end{tabular}

Besides the technology and system's operational performance debates, one must understand to what extent these projects create impacts on the lives of system users, which would lead them to changing their travel strategies due to the improvement expectation in the urban mobility index. On Table 2 there are available data from ongoing projects in Brazil.

In Belém of Pará the transportation system is not integrated yet. It is operated only by buses, a conventional transportation system. The bus lines operate the 
route district-downtown-district. Besides that, there are other urban means of transportation: the non-motorized - foot and bicycles; and the motorized - cars, vans, taxis and moto-taxis. The bus transportation is comprised of 1.2 million passengers per day. The operational fleet is comprised of 2,000 vehicles and 16,000 daily trips [10]. Nowadays there is the competition against medium sized public transport (vans and minibuses), which operates in the entire outskirts of Belém [11].

The BRT project in Belém consists in exclusive curb-side for circulation in the center of the corridors. The overtaking is done at integration stations and terminals for transference among trunk lines and feeder lines.

The buses are articulated in the trunk lines, with bus priority. In this study the region of the Augusto Montenegro Avenue will be analyzed. It has 13 kilometers in extention, three terminals and 16 stations. In Figure 1 it is possible to see the spatial configuration of the project as a whole and the location of the studied area.
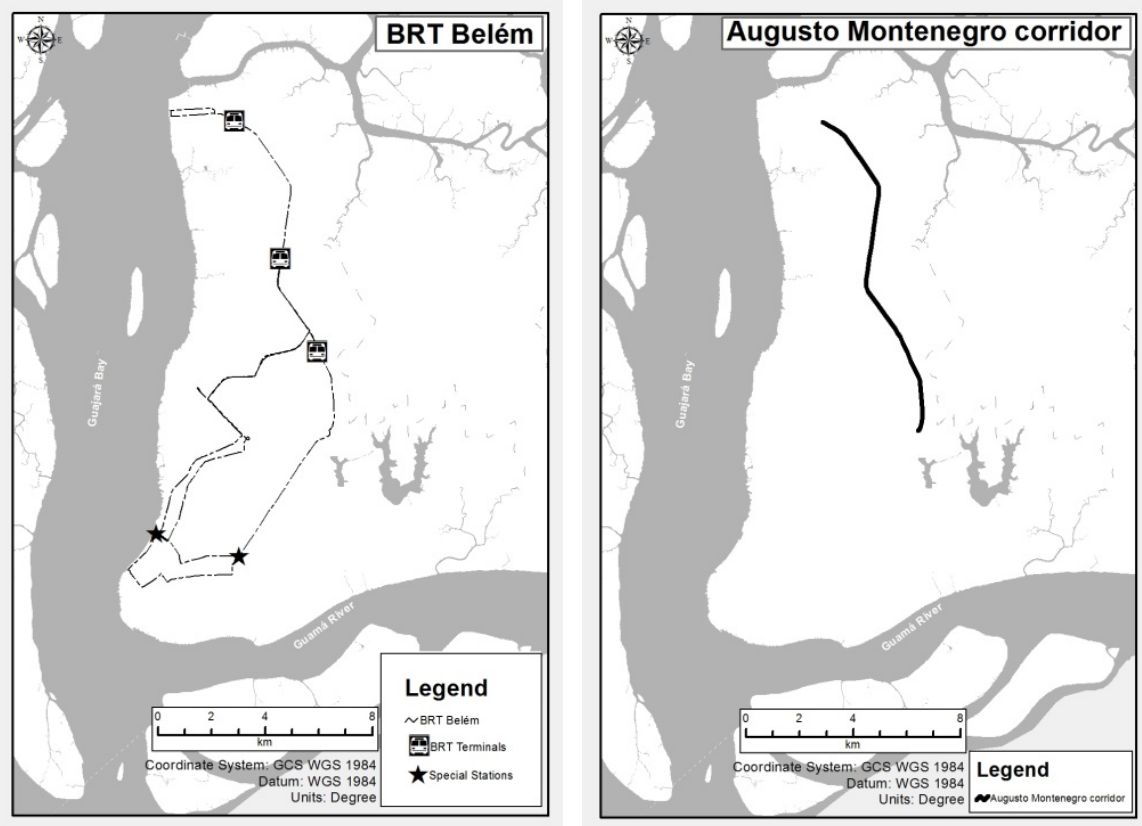

Figure 1: BRT Belém and Augusto Montenegro corridor.

In Figure 2 there is a section of the lanes and the placement of the buses on the BRT Belém. Conceptually the project contains a new operational logic for transportation in order to serve 400,000 people along the Augusto Montenegro corridor. Belém has approximately 1.5 million inhabitants. 


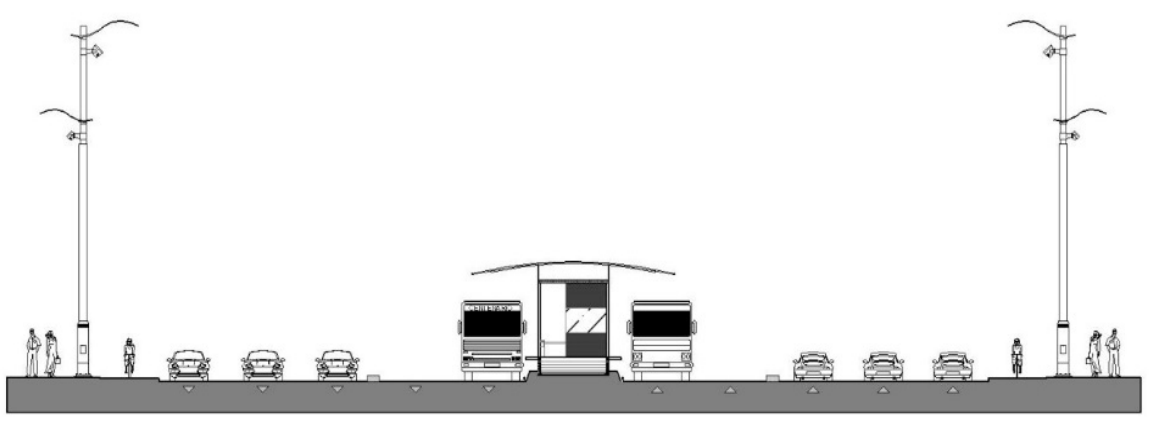

(01) $\frac{\text { AUGUSTO MONTENEGRO-LAYOUT }}{1 / 200}$

Figure 2: Section of Augusto Montenegro corridor from BRT Belem.

\section{Methodology}

The investigation was carried out within the limits of the influence area, followed by interviews with the focus groups: area inhabitants, cyclists and users of the public transport. The research used stated preference approach, based on residents of the area and, on streets, with cyclists and users of the public transport. The approach comprised of a questionnaire on social-economic characteristics, travel patterns, opinions about the current transport system, and current and future travel strategies with the project implementation.

In the spatial configuration of the project's influence area a system of geographic information was used, where it was identified the areas with greater demand for the service and those where there should be greater impact expectation. Therefore, two areas were obtained: 1 and 2.

In Areas 1 and 2, two points were selected on the Augusto Montenegro Avenue in Belém-PA, Brazil, which are part of the BRT route in the city. The first point, denominated Area 1, is located at the intersection of Augusto Montenegro Avenue and Independência Avenue; the second point or Area 2 is located at the intersection of Augusto Montenegro Avenue and Oito de Maio Street in the Icoaraci district in Belém-PA. In Table 2 there is a summary of the researched sample universe.

For determining the research points, the spatial data base was founded on the analysis dimensions, which involves considerations about the strategic importance of potential integration points associated to certain factors, such as: significant flow; favorable conditions in the surroundings for usage of the available means; existence of spontaneous integration; and presentation of viable integrations [12]. 


\section{Results}

The results are focused on the people's profile, socioeconomic and travel patterns, as well as on people's opinion about the integration expectations. They specify aspects that will facilitate the integration and the challenges. The groups revealed to be slightly different in the socioeconomic aspect. However they were very similar regarding the expectations. In this last part, it led to the presentation of answers of the total interviewees in both areas.

\subsection{Socioeconomic characteristics}

In Table 3, it is possible to observe that in Areas 1 and 2 the socioeconomic characteristics of the groups are very similar: most of them earn 1 to 2 minimum wages as income; the education is at secondary level on average; and they are relatively young. In the aspect "usage of means of transportation" there is a slight difference between the groups. In Area 1 there is a greater usage of public transport (moto-taxi and buses) and a greater usage of cars by the residents' group. In Area 2 it is predominant the individual mode of transport (bicycle, car and motorcycle). However, in the research points, it was verified the usage of public transport (buses).
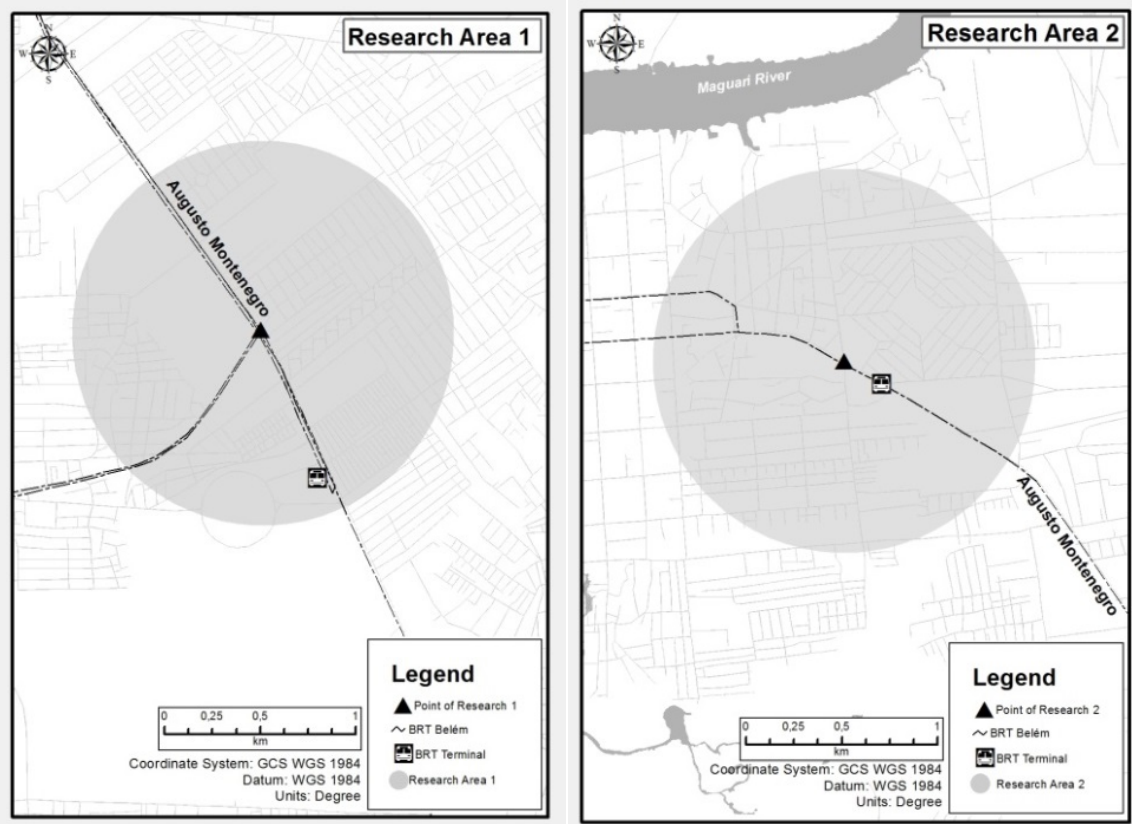

Figure 3: Research Areas 1 and 2. 
In the aspect "travel intention", it stands out in the Area 1 the importance of buses for shopping and commuting to work; while for cyclist and inhabitants, the travel intention is for commuting to work, study and leisure. In Area 2 there is the repetition of the bus importance for shopping and work. However, for cyclists work and health are more important and work, shopping and leisure are more important for inhabitants. According to the presented results, it is possible to state that the localization makes a difference on the audience profile to be served by the BRT system. In Area 1 there is a central point of the BRT route and in Area 2 there is an end point of the BRT system, where a district from Belém is located.

Table 2: Summary of field survey characteristics.

\begin{tabular}{|c|c|c|c|c|}
\hline \multirow{2}{*}{ Areas } & Type of Survey & $\begin{array}{c}\text { Persons } \\
\text { sample }\end{array}$ & Location & Study Area \\
\hline \multirow{3}{*}{1} & Volume count & 4,300 & On the road & Bus corridors \\
\cline { 3 - 5 } & $\begin{array}{c}\text { Structured } \\
\text { interviews }\end{array}$ & 134 & On the road & Bus corridors \\
\cline { 3 - 5 } 2 & Volume count & 5,134 & On household & Influence Area \\
\cline { 2 - 5 } & $\begin{array}{c}\text { Structured } \\
\text { interviews }\end{array}$ & 105 & On the road & Bus corridors \\
\cline { 3 - 6 } & \multicolumn{2}{|c}{52} & On household & Influence Area \\
\hline
\end{tabular}

Table 3: Summary of socioeconomic characteristics.

\begin{tabular}{|c|c|c|c|c|c|}
\hline Areas & Location & $\begin{array}{l}\text { Family } \\
\text { income }\end{array}$ & Education & $\begin{array}{c}\text { Age } \\
\text { bracket }\end{array}$ & Main modes \\
\hline \multirow{2}{*}{1} & $\begin{array}{l}\text { Bus } \\
\text { corridors }\end{array}$ & $\begin{array}{c}1-2 \text { wages } \\
(50 \%)\end{array}$ & $\begin{array}{c}\text { Complete } \\
\text { high school } \\
(49 \%)\end{array}$ & $\begin{array}{c}21 \text { and } 40 \\
\text { years } \\
(50 \%) \\
\end{array}$ & $\begin{array}{c}\text { Moto taxi } \\
(25 \%) \text { and } \\
\text { buses }(23 \%)\end{array}$ \\
\hline & $\begin{array}{c}\text { On } \\
\text { households }\end{array}$ & $\begin{array}{c}1-2 \text { wages } \\
(36 \%)\end{array}$ & $\begin{array}{c}\text { Complete } \\
\text { high school } \\
(42 \%)\end{array}$ & $\begin{array}{c}21 \text { and } 40 \\
\text { years } \\
(38 \%)\end{array}$ & $\begin{array}{c}\text { Car }(69 \%) \\
\text { and buses } \\
(31 \%)\end{array}$ \\
\hline \multirow{2}{*}{2} & $\begin{array}{l}\text { Bus } \\
\text { corridors }\end{array}$ & $\begin{array}{c}\text { 1-2 wages } \\
(49 \%)\end{array}$ & $\begin{array}{c}\text { Complete } \\
\text { high school } \\
(43 \%)\end{array}$ & $\begin{array}{c}21 \text { and } 40 \\
\text { years } \\
(66 \%) \\
\end{array}$ & $\begin{array}{c}\text { Bicycle } \\
(40 \%) \\
\text { buses }(27 \%) \\
\end{array}$ \\
\hline & $\begin{array}{c}\text { On } \\
\text { households }\end{array}$ & $\begin{array}{c}\text { 1-2 wages } \\
(39 \%)\end{array}$ & $\begin{array}{c}\text { Complete } \\
\text { high school } \\
(65 \%)\end{array}$ & $\begin{array}{c}21 \text { and } 40 \\
\text { years } \\
(39 \%)\end{array}$ & $\begin{array}{c}\text { Car }(65 \%) \\
\text { motorcycle } \\
(28 \%)\end{array}$ \\
\hline
\end{tabular}

\subsection{Opinion}

The opinion survey comprised four key questions for each one of the focus groups in the respective areas. There were no expressive differences in the answers for the considered areas. Therefore, the answers are conjoint presented: 
(1) What is the perspective of mobility with BRT?

(2) How does the usage of means of transportation change with BRT implementation?

(3) What is the importance of integrating the public transport with other means of transportation?

(4) How does BRT change your travel strategies?

Table 4: Travel desires.

\begin{tabular}{|c|c|c|c|c|}
\hline \multirow{2}{*}{ Areas } & Travel & \multicolumn{3}{|c|}{ Groups } \\
\cline { 3 - 5 } & intention & Bus users & Cyclist & Residents \\
\hline \multirow{4}{*}{1} & Work & $20 \%$ & $43 \%$ & $29 \%$ \\
\cline { 2 - 5 } & School & $8 \%$ & $12 \%$ & $27 \%$ \\
\cline { 2 - 5 } & Health & - & $2 \%$ & - \\
\cline { 2 - 5 } & Shopping & $46 \%$ & $11 \%$ & $19 \%$ \\
\cline { 2 - 5 } & Leisure & $18 \%$ & $29 \%$ & $25 \%$ \\
\cline { 2 - 5 } & Other & $8 \%$ & $3 \%$ & - \\
\hline \multirow{4}{*}{2} & Work & $36 \%$ & $38 \%$ & $36 \%$ \\
\cline { 2 - 5 } & School & $9 \%$ & $5 \%$ & $2 \%$ \\
\cline { 2 - 5 } & Health & - & $39 \%$ & - \\
\cline { 2 - 5 } & Shopping & $46 \%$ & $14 \%$ & $31 \%$ \\
\cline { 2 - 5 } & Leisure & $9 \%$ & $3 \%$ & $27 \%$ \\
\cline { 2 - 5 } & Other & - & $1 \%$ & $4 \%$ \\
\hline
\end{tabular}

\section{For bus users}

(1) I will be able to perform faster trips (35\%); I will be able to use the bicycle with the bus (25\%); the cost of my trips will be lower (15\%).

(2) I will use buses more often (50\%); it does not change anything, because I always use the bus (30\%); I will use the bicycle up to the bus stop (16\%).

(3) Very important (8\%) and important (62\%).

(4) I will be able to do more trips (33\%); I will be able to do more activities during the day $(17 \%)$.

\section{For cyclists}

(1) I will use buses more often (53\%); it does not change anything, because I like riding the bicycle (37\%).

(2) I will use the bicycle combined with BRT, as long as there is a bicycle parking lot (49\%); it does not change anything; I keep using buses (26\%); it does not change anything, because I do not have enough income to use buses (6\%); I will stop using the bicycle and I will only use the $B R T(4 \%)$.

(3) Very important (11\%) and important (74\%). In this item it stood out that most of inhabitants own a bicycle at home (73\%).

(4) I will be able to use the bicycle to arrive at the bus stop (60\%); I will be able to do more trips during the day (23\%). 


\section{For residents}

(1) I will do faster trips (25\%); I will be able to do more trips a day (23\%); the cost of my trips will be lower (9\%).

(2) I will use buses more often (28\%); I will be able to use the bicycle combined with (17\%); it does not change anything, because I always use buses $(10 \%)$.

(3) Very important (16\%) and important (70\%).

(4) I will be able to do more activities during the day (30\%); I will have more time for new activities (13\%); I will use buses more often (7\%).

Despite the slight socioeconomic difference among the surveyed groups, the answers about the impacts of the mobility system are very similar and they are focused on: decrease of travel duration; potential of doing more activities per trip; integrated usage of bus and bicycle; and saving money with fare collection. Another observed aspect is the importance of bicycle for commuting to work, which emphasizes the relevance for searching integration between bicycles and buses.

\section{Final remarks}

During the empirical research, with some key questions that conducted the survey process, it was possible to assess the direct impact that an integrated transport system like BRT has over a certain urban population. Such impacts ensure the benefits that this system could bring to the population and highlight the great expectation that the population has about it. In general what was obtained in Belém regarding the opinion of the population about the BRT is something that can be also observed in several Brazilian cities where the projects are ongoing.

Therefore, it is possible to state that many things can be changed in the travel strategies of people using BRT, because it is a system with an operational logic that is totally different from what is existent in the country in terms of public transport for a population which has the expectation of mobility increase.

Among the challenges to be faced, regarding Belém, which does not own an integrated system, there would be decreasing the transboarding costs, because this is something not experienced by the population with the current system. Therefore, they are not able to evaluate it previously.

\section{Acknowledgements}

The authors would like to thank CNPq and CAPES, which supported the research; the contributions from experts, which allowed the improvement of the work; and the researchers and scholars from Universidade da Amazônia and Universidade Federal UFPA and their study group. 


\section{References}

[1] Ministério das cidades. Secretaria Nacional de Transporte e da Mobilidade Urbana. Manual do BRT - Bus Rapid Transit (2008).

[2] Vasconcellos, E. A. Transporte urbano nos países em desenvolvimento: reflexões e propostas. São Paulo: Unidas, 1996.

[3] Cançado, V. L. A opinião do usuário sobre transporte por ônibus. Revista dos Transportes Públicos, 19 (73), p. 33-50, 1996.

[4] Jones, P. M. New approaches to understanding travel behavior: the human activity approach. Transport Studies, working paper, 28, Oxford, 1977.

[5] Hagerstrand, T. What about people in regional science? Papers of regional science association, 24, p. 7-21, 1970.

[6] Jones, P. M., D. Ix, M. C., Clarke, M. \& Heggie, I. G. Understanding travel behavior. Gower Publishing, Aldershot, 1983.

[7] Goodwin, P., Kitamura, R. \& Meurs, H. Some principles of dynamic analysis of travel behavior. In: Development in dynamic and activity-based approaches to travels analysis. England, Goer, 1990.

[8] Reis, H. S., Aragão, J. J. \& Yamashita, Y. Avaliação da sensibilidade aos atributos do serviço de ônibus como instrumentos de competitividade para operadores de ônibus frente ao transporte alternativo, Congresso de Pesquisa e Ensino em Transportes, 16, Anais, Natal, Brazil, 2, p. 187-198, 2002.

[9] Karsaklian, E. Comportamento do consumidor. São Paulo: Atlas, 2000.

[10] SeMOB - Superintendência de Mobilidade Urbana de Belém. Dados estatísticos. Belém, Brazil, 2014.

[11] Tobias, M. S. G., Neves, P. B. T. \& Corrêa, P. H. P.. Transporte clandestino: uma face da crise do transporte urbano na Região Metropolitana de Belém. Revista dos Transportes Públicos, 32, 2o quadrimestre, p. 47-57, 2010.

[12] Cervero, R. \& Kockelman, K. Travel demand and the 3D's: density, diversity and design. Transportation Research Part D, 2 (3), p. 199-219, 1997. 